\title{
Yersinia arthritis: a clinical, immunological, and family study of 2 cases
}

\author{
P. J. H. S. SHELDON ${ }^{1}$ N. S. MAIR, ${ }^{2}$ AND E. FOX ${ }^{3}$
}

From the ${ }^{1}$ Department of Rheumatology, Leicester Royal Infirmary, the ${ }^{2}$ Department of Microbiology, University of Leicester, and the ${ }^{3}$ Public Health Laboratory, Leicester

SUMMARY We describe 2 patients who presented with yersinia arthritis within a period of 5 months in Leicester. Both were HLA B27 positive. Arthritis followed 2 to 3 weeks after pneumonia, abdominal pain, dysuria, and evidence of hepatic involvement in the first case, and dysuria and conjunctivitis in the second. Immunological studies showed the presence of $\operatorname{IgM}, \operatorname{IgG}, \operatorname{and} \operatorname{IgA}$ antibodies at a significant level against Yersinia enterocolitica serotype O:3 in serum and synovial fluid, and immune complexes in the serum of the first case and synovial fluid of both. Arthropathy resolved after 16 weeks in the first case and 12 weeks in the second, the latter requiring systemic corticosteroids. Family studies revealed psoriatic spondylarthritis in the brother, and bilateral sacroiliitis in the mother of the second case. Both were HLA B27 positive. These are the fourth and fifth reported cases of yersinia arthritis in Britain. We believe the condition is probably underdiagnosed and that yersiniosis should be considered as a possibility in otherwise unexplained arthritis.

Reactive arthritis is an aseptic arthritis occurring in patients known to have had recent infection with salmonella, ${ }^{12}$ shigella,${ }^{34}$ gonococcus,${ }^{5}$ meningococcus, ${ }^{6}$ campylobacter, ${ }^{78}$ chlamydia,${ }^{9}$ or yersinia ${ }^{10-12}$ The florid form of the disease, including mucocutaneous and ocular lesions as described by Reiter, occurred in a man 1 week after an attack of diarrhoea. ${ }^{13}$

Though quite commonly encountered in Scandinavia, there have been few reports of reactive arthritis or Reiter's disease associated with Yersinia enterocolitica infection in the United Kingdom. Thus between 1970 and 1976 there were only 2 reported cases of $Y$. enterocolitica infection and neither had arthritis. ${ }^{14} 15$ Both were probably infected while abroad. Three cases with arthritis were subsequently described. ${ }^{16-18}$

We report 2 cases seen within a 5-month period in Leicester, together with a study of their families with particular respect to the occurrence of HLA B27, known to be involved in reactive arthritis. ${ }^{19}$

\footnotetext{
Accepted for publication 23 March 1981.
}

Correspondence to Dr P. J. H. S. Sheldon, Department of Rheumatology, Leicester Royal Infirmary, Infirmary Square, Leicester LE1 5WW.

\section{Case reports}

CASE 1

A 33-year-old male bank clerk developed sudden left-sided chest pain extending to the left hypochondrium and made worse on breathing. There was no cough or sputum. He also had colicky lower abdominal pain but no diarrhoea. Dysuria was present and persisted intermittently for 1 week. There was no history of conjunctivitis. On examination he was apyrexial. A pleural rub was detected over the left lower zone posteriorly and there was tenderness with guarding in the left hypochondrium. Bowel sounds and rectal examination were normal. At this stage his midstream urine showed $21 \times 10^{6} / 1$ white blood cells and no growth on culture. Chest $x$-ray showed consolidation in the posterior segment of the left lower lobe. Liver function tests showed $\gamma$-glutamyl transferase $90 \mathrm{IU} / 1$ (normal 0-50), alanine transaminase $112 \mathrm{IU} / 1$ (normal 0-35), aspartate transaminase 66 IU/l (normal 8-40), and alkaline phosphatase 351 IU/l (normal 60-260). Blood culture was sterile.

$\mathrm{He}$ was thought to have a chest infection and received a 10-day course of doxycycline $100 \mathrm{mg}$ daily. The chest $x$-ray cleared over the next week, but there was persistent pain in the hips and legs. Sixteen days 
from the onset of illness there was painful swelling of the right knee and at 21 days of the right shoulder. Liver function tests were repeated and showed worsening of the previously reported changes, suggesting the presence of hepatitis, though the bilirubin level remained normal. Further investigations were as follows: haemoglobin $13.8 \mathrm{~g} / \mathrm{dl}$; white blood cell count $11.8 \times 10^{9} / 1$; plasma viscosity $2.2 \mathrm{cp}$; urea $7 \cdot 1$ $\mathrm{mmol} / \mathrm{l}(43 \mathrm{mg} / 100 \mathrm{ml})$; antistreptolysin O titre 200 IU/l. Complement fixing antibodies to influenza A and B, adenovirus, Coxiella burnetti, Chlamydia psittaci, and Mycoplasma pneumoniae were negative. Tests for hepatitis B surface antigen, rheumatoid factor, and antinuclear factor were negative. Liver ${ }^{99} \mathrm{Tc}$ scan and electrocardiogram were normal. Knee aspirate was sterile, and pathogens were not isolated from stool cultures. Agglutinating antibodies to $Y$. enterocolitica serotype 0:3 were present at a reciprocal titre of 640 in both serum and joint fluid (Fig. 1)
Details of immunological studies on blood and synovial fluid are shown in Tables 1 and 2.

During the next 7 weeks he developed bilateral knee effusions and pain in the dorsum of the left foot, while the pain in the right shoulder persisted. He was treated with nonsteroidal anti-inflammatory drugs (NSAID) and intra-articular steroid injections to the knees and right shoulder. At review 18 weeks after onset of illness he was well, at work for the past 2 weeks, but with slight residual shoulder pain and limitation of movement. He was off all drugs.

The patient's family was studied and their HLA B27 status determined. (Fig. 2).

\section{CASE 2}

A 22-year-old bus mechanic attended the emergency department complaining of pain and swelling of the right foot of 1 week's duration and of the left ankle for 4 days. Three weeks previously he had had painful

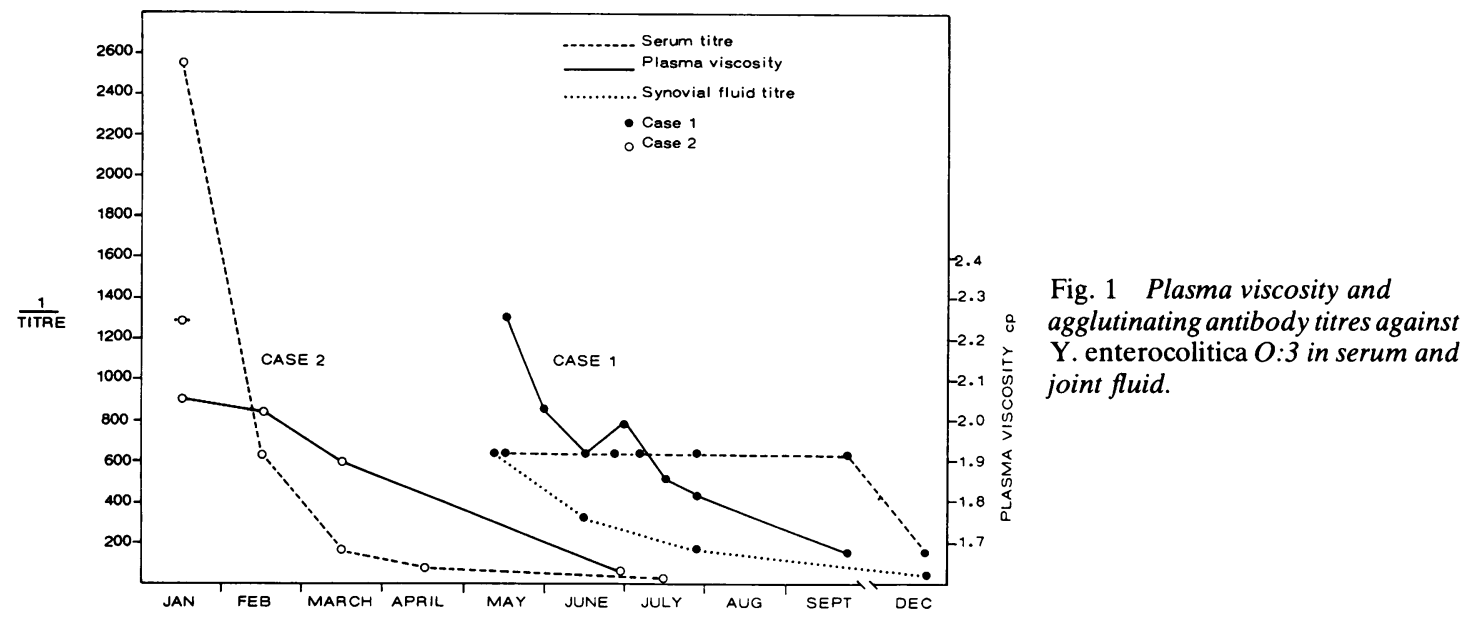

Table 1 Immunological studies on peripheral blood and synovial fluid in 2 cases of yersinia arthritis

\begin{tabular}{|c|c|c|c|c|}
\hline & \multicolumn{2}{|l|}{ Case 1} & \multicolumn{2}{|l|}{ Case 2} \\
\hline & Blood & Synovial fluid & Blood & Synovial fluid \\
\hline Total white cell count & $11.8 \times 10^{\%} / 1$ & - & $6.4 \times 10 \%$ & $10.5 \times 10^{2} / 1$ \\
\hline \% Neutrophils & - & $18,80^{\mathrm{f}}$ & 72 & 61 \\
\hline \% Lymphocytes & - & $58^{\mathrm{g}}, 20^{\mathrm{f}}$ & 24 & 33 \\
\hline$\% \mathrm{~T}_{\text {cells }}^{\mathrm{a}}$ & 69 & 56 & 66 & 80 \\
\hline$\%$ B cells $^{\mathrm{h}}$ & 19 & 7 & 14 & 10 \\
\hline Resting ${ }^{3} \mathrm{H}$ thymidine uptake ${ }^{\mathrm{c}}$ & $924 \mathrm{cpm}$ & - & $379 \mathrm{cpm}$ & $2082 \mathrm{cpm}$ \\
\hline Max. response to phytohaemagglutinin ${ }^{c}$ & $12007 \mathrm{cpm}$ & - & $35951 \mathrm{cpm}$ & $22943 \mathrm{cpm}$ \\
\hline Glucose concentration & $4.0 \mathrm{mmol} / \mathrm{l}$ & $4 \cdot 1 \mathrm{mmol} / 1$ & $4 \cdot 0 \mathrm{mmol} / 1$ & $4.8 \mathrm{mmol} / \mathrm{l}$ \\
\hline $\mathrm{C}^{\mathrm{d}}$ & $12.6 \mu \mathrm{mol} / \mathrm{l}$ & $7.5 \mu \mathrm{mol} / \mathrm{l}$ & - & $11 \cdot 7 \mu \mathrm{mol} / \mathrm{l}$ \\
\hline $\mathrm{C}^{\mathrm{d}}$ & $2.6 \mu \mathrm{mol} / \mathrm{l}$ & $0.96 \mu \mathrm{mol} / 1$ & - & $0.4 \mu \mathrm{mol} / 1$ \\
\hline Titres of immune complexes $e$ & $1: 4$ & $1: 8$ & - & $1: 4$ \\
\hline Y. ent. $0: 3$ maximum agglutination titres & $1: 640$ & $1: 640$ & $1: 2560$ & $1: 1280$ \\
\hline
\end{tabular}

astimated by $\mathbf{E}$ rosette formation..$^{37}$ bstimated by rosetting with antiglobulin-coated chromic chloride treated erythrocytes. ${ }^{36}{ }^{c}$ Estimated by micromethod; each result represents mean of triplicate cultures. ${ }^{30} \mathrm{~d}$ Estimated by single radial immunodiffusion. ${ }^{40}$ eEstimated by platelet aggregation. ${ }^{41}{ }^{8}$ Samples taken 3 days apart. 8 24\% Large mononuclear cells also present.

Conversion of SI to traditional units: Glucose $1 \mathrm{mmol} / \simeq 18 \mathrm{mg} / 100 \mathrm{ml} . \mathrm{C} 31 \mu \mathrm{mol} / \sim_{18.5} \mathrm{mg} / 100 \mathrm{ml}(\mathrm{normal} 3.9-10 \mu \mathrm{mol} / \mathrm{l}) . \mathrm{C} 41 \mu \mathrm{mol} / \mathfrak{\imath} 23.0 \mathrm{mg} / 100 \mathrm{ml}$ (normal 0.6-2.9 $\mu \mathrm{mol} / \mathrm{l}$ ). 
Table $2 \operatorname{IgM}, \operatorname{IgG}$, and $\operatorname{Ig} A$ antibodies to $\mathrm{Y}$. enterocolitica $O: 3$ determined by indirect immunofluorescence in serum and joint aspirate specimens at intervals after onset of yersinia arthritis

\begin{tabular}{|c|c|c|c|c|c|c|}
\hline \multirow[t]{2}{*}{ Case } & \multirow{2}{*}{$\begin{array}{l}\text { Immunoglobulin } \\
\text { class }\end{array}$} & \multicolumn{5}{|c|}{ Serum and joint aspirate antibody titres at } \\
\hline & & 2-4 weeks & 2 months & 3 months & 4 months & 7 months \\
\hline 1 & $\begin{array}{c}\text { IgM } \\
\text { IgG } \\
\text { IgA }\end{array}$ & $\begin{array}{l}200 / 200^{*} \\
400 / 800 \\
100 / 100\end{array}$ & $\begin{array}{r}100 / 200 \\
200 / 800 \\
50 / 100\end{array}$ & $\begin{array}{c}50 / 200 \\
200 / 200 \\
50 / 50\end{array}$ & $\begin{array}{c}200 /-{ }^{* *} \\
50 /- \\
50 /-\end{array}$ & $\begin{array}{r}100 / 0 \\
200 / 0 \\
0 / 0\end{array}$ \\
\hline 2 & $\begin{array}{l}\text { IgM } \\
\text { IgG } \\
\text { IgA }\end{array}$ & $\begin{array}{l}1600 / 200 \\
1600 / 800 \\
1600 / 400\end{array}$ & $\begin{array}{r}100 /- \\
400 /- \\
0 /-\end{array}$ & $\begin{array}{r}50 /- \\
400 /- \\
0 /-\end{array}$ & $\begin{array}{r}0 /- \\
100 /- \\
0 /-\end{array}$ & $\begin{array}{l}0 /- \\
0 /- \\
0 /-\end{array}$ \\
\hline
\end{tabular}

*Reciprocal titres of serum and joint aspirate, e.g. $200 / 200=$ serum $1: 200 /$ joint aspirate $1: 200{ }^{* *}-=$ No joint aspirate.

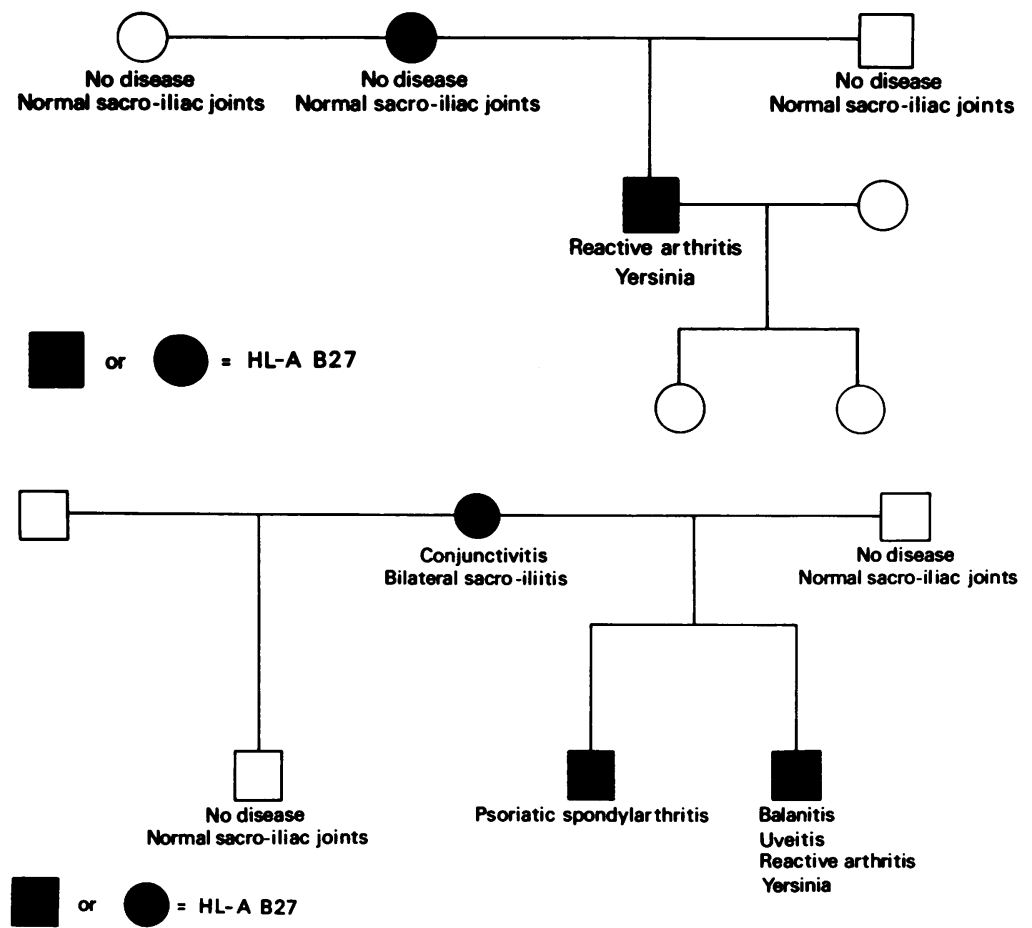

Fig. 2 Family pedigree of case 1.

Fig. 3 Family pedigree of case 2 showing presence of arthritis in HLA B27 positive members of the family.

eyes and dysuria lasting 2 days. There was no history of backache, bowel disturbance, or sexual exposure. At the age of 8 years he had undergone circumcision for recurrent attacks of balanitis attributed to phimosis. At 11 years he had had acute iridocyclitis of the right eye and at 16 years the left eye had been similarly affected. One brother was said to have 'arthritis', the rest of the family being well.

Examination revealed tenderness over the dorsum of the right foot and synovial swelling and tenderness of the left ankle. Subsequently he developed effusions in both knees and a flitting arthropathy involving metacarpophalangeal and metatarsophalangeal joints. Investigations were as follows: haemoglobin $14.8 \mathrm{~g} / \mathrm{dl}$; white blood cell count $7.6 \times 10^{9} / 1$; plasma viscosity $2.02 \mathrm{cp}$; serum urate $0.256 \mathrm{mmol} / \mathrm{l}(4 \cdot 3$ $\mathrm{mg} / \mathrm{dl}$ ); rheumatoid factor negative; stool culture negative; radiographs of chest, spine, and pelvis normal; electrocardiogram normal. Serum and joint fluid taken 14 days after onset of arthritis showed agglutinating antibodies to $Y$. enterocolitica $\mathrm{O}: 3$ at reciprocal titres of 2560 and 1280 respectively (Fig. 1). The results of immunological studies on blood and synovial fluid are shown in Tables 1 and 2 .

He was treated with NSAID for 5 weeks and tetracycline $250 \mathrm{mg}$ four times daily for $\mathbf{1 0}$ days empirically in view of the serological evidence of acute yersinia infection. He also received corticosteroid injections into both knee joints. He was unable to return to work on account of persistently painful feet 
and was therefore started on prednisolone $15 \mathrm{mg}$ daily. The joints became less painful, and the dose was reduced over a 7-week period, by which time all the drugs were discontinued, the patient being free of symptoms apart from an occasional twinge. He was able to return to work 12 weeks after the onset of illness. His family was studied and their HLA B27 status assessed (Fig. 3).

\section{Discussion}

The first case was initially very puzzling, with a combination of abdominal and chest symptoms. The diagnosis was suspected only after the appearance of arthritis. In both patients this predominantly involved the lower limbs, though the shoulder and metacarpophalangeal joints were also affected. Similar patterns of joint involvement have been recorded in other series, including migrating arthralgia. ${ }^{11-13}$ The duration of arthritis was approximately 4 months and 3 months respectively in cases 1 and 2 , but it must be remembered that the second case received systemic corticosteroids 5 weeks after the onset of joint pains, enabling him to return to manual work 7 weeks later. Generally speaking case 2 had a more florid arthritis, with a failure to respond to NSAID therapy. Case 1 presented with systemic illness, the subsequent joint symptoms responding adequately to NSAID, enabling him to return to clerical work. Additionally there was biochemical evidence of hepatic involvement which improved with his arthritis. Hepatitis in $Y$. enterocolitica infection has previously been described. ${ }^{20}{ }^{21}$

The titre of agglutinating antibody to $Y$. enterocolitica $0: 3$ in the serum of case 1 remained constant at 640 for at least 4 months, whereas in the synovial fluid antibody began to decline after 1 month, though it could still be detected 2 months later. In the second case serum antibody fell within 1 month, that is, before systemic corticosteroids were administered (Fig. 1). The antibody classes involved were shown by indirect immunofluorescence to include $\operatorname{IgM}, \operatorname{IgG}$, and $\operatorname{IgA}$ (Table 2). All 3 classes were present in both serum and synovial fluid. IgM antibodies to yersinia were surprisingly persistent in case 1 , being still detectable after 7 months, while in case 2 a striking feature was the rapid disappearance of $\operatorname{IgA}$ antibodies in less than 2 months. These findings differ from those of a recent study in Finland by Granfors et al. ${ }^{22}$ who showed that in patients with severe yersinia arthritis IgM antibodies persisted in most cases for only 1 to 3 months and always disappeared during the first 6 months after onset of infection, while IgA antibodies to yersinia persisted for 14-16 months after onset of infection. Different methodology may account for these differences, since Granfors et al. used the enzyme-linked immunosorbent assay technique to demonstrate the 3 immunoglobulin classes. As an explanation for the persistence of $\operatorname{IgA}$ antibodies the same investigators mention the possibility of antigenic stimulation from the gut and genitourinary tract (perhaps understandable in a country such as Finland, where human yersinia infection is endemic).

The joint fluid in both cases showed a polymorphonuclear neutrophil leucocytosis, though in the first case it was of interest to note that the ratio of lymphocytes to polymorphs in synovial aspirates from the same knee 3 days apart showed a reversal at a time when immune complexes were detected (Table 1). The levels of $\mathrm{C} 3$ and $\mathrm{C} 4$, though within the normal range, were lower in synovial fluid than blood at this time, possibly as a result of classical pathway activation.

The percentage of thymic derived (T) and thymic independent (B) lymphocytes in blood and joint fluid were similar (Table 1), as was the response to phytohaemagglutinin (PHA), whereas in rheumatoid arthritis $B$ cell percentages in synovial fluid may differ from those in blood, and the synovial fluid lymphocytes are relatively refractory to stimulation by PHA. ${ }^{23}$

The history of 'arthritis' involving the brother of the second case prompted a limited study of both families, the results being shown in Figs. 2 and 3. The mother of the first case was HLA B27 positive, but neither she nor her sister (B27 negative) had clinical or radiological evidence of arthropathy. The brother of the second case was found to have psoriasis, with nail pitting and onycholysis. He also had an asymmetrical polyarthritis and bilateral radiological sacroiliitis. The mother had a 2-year history of low back pain and 10 years previously had required outpatient treatment over a 1-month period for conjunctivitis. $X$-ray revealed bilateral sacroiliitis. Both relatives were B27 positive. The father and a half-brother, both B27 negative, were clinically and radiologically normal. No other members of either family had antibodies to $Y$. enterocolitica $\mathrm{O}: 3$.

Reactive arthritis is generally self-limited and is a benign variant within the spectrum of seronegative spondylarthropathies. At the centre of this spectrum lies ankylosing spondylitis (AS), a disorder marked by chronic progressive disability, yet the insidious nature of its onset and course make the role of an infectious agent extremely difficult to substantiate. The close association of B27 with AS and other spondylarthropathies ${ }^{24-26}$ has evoked much speculation on the mechanisms likely to be involved. Immune responses are known to be in part genetically determined in various species, including the mouse and probably man. ${ }^{27}$ In the mouse overall high 
or low antibody responses have been demonstrated to a variety of antigens, and this finding has been attributed to differences in antigen handling by macrophages. ${ }^{28}{ }^{29}$ Specific responses to some antigens have been shown to be under the control of autosomal dominant immune response (Ir) genes which are linked to the major histocompatibility system (MHS). ${ }^{30}$ The chronological sequence of events in B27-associated reactive arthritis may illustrate the interplay of infection and genetic factors, though the mechanism may not necessarily involve the (probable) linkage of the MHS to Ir genes. The 'molecular mimicry' hypothesis suggests that there is antigenic similarity between the B27-coded HLA molecule on the cell surface and determinants on certain bacteria. Consequently antibodies formed as a result of infection may cross-react with host tissues (as is thought to be the case in rheumatic fever). Alternatively the aberrant response, by its failure effectively to clear the antigen load, may result in a state of antigen excess and the formation of soluble immune complexes, which could in turn play a part in the ensuing arthritis.

Studies showing an increased incidence of faecal carriage of Klebsiella aerogenes in patients with $\mathrm{AS}^{31}$ have been followed by evidence that antiserum raised in rabbits against certain isolates of $K$. aerogenes will kill B27 positive $(\mathrm{B} 27+) \mathrm{AS}+$ lymphocytes, but not $\mathrm{B} 27+\mathrm{AS}-, \mathrm{B} 27-\mathrm{AS}-$, or B27-4 AS + lymphocytes $^{32}$ Subsequently the same workers demonstrated that a soluble factor derived from a klebsiella K43 culture filtrate was able specifically to modify a B27-associated lymphoid cell component, rendering previously nonsusceptible B27+ lymphocytes susceptible to cytotoxicity by rabbit anti-klebsiella antiserum. $^{33}$

In an attempt to find a similar link between $Y$. enterocolitica and AS other workers have raised antisera in rabbits against 3 strains of $Y$. enterocolitica, including serotype $0: 3$. These antisera failed to exhibit cytotoxic activity against $\mathrm{B} 27+\mathrm{AS}+$, $\mathrm{B} 27+\mathrm{AS}-$, or B27 - lymphocytes, nor was the activity of anti-B27 typing serum absorbed out by yersinia antigen preparations. ${ }^{34}$

The true relationship between $K$. aerogenes, $Y$. enterocolitica, and B27 remains far from clear. Nevertheless one is tempted to postulate that in acute reactive arthritis gut infection results in a genetically determined pattern of immune response resulting in antibody synthesis and circulating immune complexes. In contradistinction faecal carriage of an organism in a genetically predisposed individual may act in 2 ways, firstly, as in the case of gut infection with the formation of immune complexes, which have been demonstrated in $\mathrm{AS}^{35}$ and secondly through a perturbation of a cell wall component of B27-positive gut-associated lymphocytes by cytophilic bacterial cell products. ${ }^{33}$ This in turn may trigger the release of lymphokines into Batson's circulation, ${ }^{36}$ with the development of chronic inflammation and its sequelae along the appropriate channels of spread, with the clinical development of changes recognised as AS.

We thank Dr H. Thurston for permission to investigate the first case and Miss Elaine Gooch for help with the immunofluorescence tests.

\section{References}

1 Vairtainen J, Hurri L. Arthritis due to Salmonella typhimurium. Acta Med Scand 1964; 175: 771-6.

${ }^{2}$ Warren C P W. Arthritis associated with salmonella infections. Ann Rheum Dis 1970; 29: 483-7.

${ }^{3}$ Paronen I. Reiter's disease, a study of 344 cases observed in Finland. Acta Med Scand 1948; 131 (suppl 213): 1-114.

4 Noer H R. An experimental epidemic of Reiter's syndrome. JAMA 1966; 198: 693-8.

5 Rosenthal L, Olhagen B. Report given at IVth Congress of the South-East Asia and Pacific Area League against Rheumatism 1980.

${ }^{6}$ Greenwood B M, Whittle H C. The pathogenesis of meningococcal arthritis. In: Dumonde D C, ed. Infection and Immunology in the Rheumatic Diseases. Oxford: Blackwell, 1976: 119-27.

' Urman J D, Zurier R B, Rothfield N F. Reiter's syndrome associated with Campylobacter fetus infection. Ann Intern Med 1977; 86: 444-5.

- Berden J H M, Muytjens H L, van de Putte L B A. Reactive arthritis associated with Campylobacter jejuni enteritis. Br Med J 1979 ; i: $380-1$.

- Keat A C, Thomas B J, Taylor-Robinson D, Pegrum G D, Maini R N, Scott J T. Evidence of Chlamydia trachomatis infection in sexually acquired reactive arthritis. Ann Rheum Dis 1980; 39: 431-8.

${ }^{10}$ Ahvonen P, Sievers K, Aho K. Arthritis associated with Yersinia enterocolitica infection. Acta Rheumatol Scand 1969; 15: 232-53.

11 Ford D K. Yersinia-induced arthritis and Reiter's syndrome. Ann Rheum Dis 1979; 38 (suppl 1): 127-8.

12 Laitinen O, Tuuhea J, Ahvonen P. Polyarthritis associated with Yersinia enterocolitica infection. Ann Rheum Dis 1972;31: 34-9.

13 Reiter H. Ueber eine bisherunbekannte Spirochaeteninfektion (Spirochaetosis arthritica). Dtsch Med Wochenschr 1916; 42: $1535-6$.

14 Chessum B, Frengley J D, Fleck D G, Mair N S. Case of septicaemia due to Yersinia enterocolitica. Br Med J 1971; iii: 466.

15 Baldock N E, Catterall M D. Erythema nodosum from Yersinia enterocolitica. Br J Dermatol 1975; 93: 719-20.

${ }_{16}$ Scott J T, Mair N S. Yersinia Arthritis. Br Med J 1979; i: 1251.

${ }^{17}$ Bulgen D Y, Hazleman B L, Warren R E. Arthritis and neuralgic amyotrophy due to Yersinia enterocolitica. Br Med J 1979; i: 1250-1.

${ }^{18}$ Dunk A A, Dobbie D T, Pitkeathly D A. Reactive arthritis following asymptomatic Yersinia infection. Scott Med J 1980; 25: 327-8.

19 Aho K, Ahvonen P, Alkio P, et al. HL-A 27 in reactive arthritis following infection. Ann Rheum Dis 1975; 34 (suppl): 29-30.

${ }^{20}$ Leino R, Kalliomaki J L. Yersiniosis as an internal disease. Ann Intern Med 1974; 81: 458-61.

${ }^{21}$ Bakken A F. Yersinia infection with hepatitis in a physician. Lancet 1975; ii: 1316.

${ }^{22}$ Granfors K, Viljanen M, Tiilikainen A, Toivanen A. Persistence of IgM, IgG and IgA antibodies to Yersinia in Yersinia arthritis.J Infect Dis 1980; 141: 424-9. 
${ }^{23}$ Sheldon P J, Papamichail M, Holborow E J. Studies on synovial fluid lymphocytes in rheumatoid arthritis. Ann Rheum Dis 1974; 33: 509-14.

24 Brewerton D A, Caffrey M, Hart F D, James D C O, Nicholls A, Sturrock R D. Ankylosing spondylitis and HL-A 27. Lancet 1973; i: 904-7.

${ }^{25}$ Schlosstein L, Terasaki P I, Bluestone R, Pearson C M. High association of an HL-A antigen, W27 with ankylosing spondylitis. N Engl J Med 1973; 288: 704-6.

${ }^{26}$ Masi A T. Epidemiology of B27-associated diseases. Ann Rheum Dis 1979; 38 (suppl): 131-4.

${ }^{27}$ Benacerraf B, McDevitt H O. Histocompatibility-linked immune response genes. Science 1972; 175: 273-9.

${ }^{2 y}$ Biozzi G, Stiffel C, Mouton D, Bouthillier Y, Decreusfond C. Cytodynamics of the immune response in two lines of mice genetically selected for 'high' and 'low' antibody synthesis. J Exp Med 1972: 135: 1071-94.

29 Wiener E, Bandieri A. Differences in antigen handling by peritoneal macrophages from the Biozzi high and low responder lines of mice. Eur J Immunol 1974; 4: 457-6.3

${ }^{30}$ McDevitt H O, Chinitz A. Genetic control of the antibody responses: relationship between immune response and histocompatibility (H-2) type. Science 1969; 163: 1207-8.

${ }^{31}$ Ebringer R W, Cawdell D R, Cowling P, Ebringer A. Sequential studies in ankylosing spondylitis. Ann Rheum Dis 1978; 37: 146-51.

${ }^{32}$ Seager K, Bashir H V, Geczy A F, Edmonds J, de Vere-Tyndall A.
Evidence for a specific B27-associated cell surface marker on lymphocytes of patients with ankylosing spondylitis. Nature 1979; 277: 68-70.

${ }^{33}$ Geczy A F, Alexander K, Bashir H V, Edmonds J. A factor(s) in Klebsiella culture filtrates specifically modifies an HLA-B27associated cell surface component. Nature 1980; 283: 782-4.

${ }^{34}$ Pease P, England J, Tyler R. HLA B27, Yersinia enterocolitica and ankylosing spondylitis. Ann Rheum Dis 1980; 39: 415-6.

${ }^{35}$ Corrigall V, Panayi G S, Unger A, Poston R N, Williams B D. Detection of immune complexes in serum of patients with ankylosing spondylitis. Ann Rheum Dis 1978; 37: 159-63.

${ }^{36}$ Romanus R. Pelvo-spondylitis ossificans in the male (morbus Bechterew-Marie-Strümpell) and genito-urinary infections. Acta Med Scand 1953; 145 (suppl 280): 1-368.

${ }^{37}$ Lay W H, Mendes N F, Bianco C, Nussensweig V. Binding of sheep red blood cells to a large population of human lymphocytes. Nature 1971; 230: 531-2.

${ }^{38}$ Dhaliwal H S, Ling N R, Bishop S, Chapel H. Expression of immunoglobulin $\mathrm{G}$ on blood lymphocytes in chronic lymphatic leukaemia. Clin Exp Immunol 1978; 31: 226-36.

39 Thorpe P E, Knight S C. Microplate cultures of mouse lymph node cells. J Immunol Methods 1974; 5: 387-404.

${ }^{40}$ Mancini C, Carbonara A O, Heremans J F. Immunochemical quantitation of antigens by single radial immunodiffusion. Int $J$ Immunochem 1965; 2: 235-54.

${ }^{41}$ Myllylä G. Aggregation of human blood platelets by immune complexes in the sedimentation pattern test. Scand J Haematol 1973; suppl 19: 1-56. 